\title{
Efficiency of Fertilization and Utilization of Nitrogen and Sulphur by Spring Wheat
}

\author{
Hanna Klikocka*, Magdalena Cybulska, Anna Nowak \\ Faculty of Agrobioengineering, University of Life Science in Lublin, \\ 13 Akademicka St. 20-950 Lublin, Poland
}

Received: 17 January 2017

Accepted: 28 March 2017

\begin{abstract}
The aim of our study was to evaluate the effects of nitrogen $(\mathrm{N})$ and sulphur (S) fertilizer on harvest index (HI), agronomic efficiency (AE), physiological efficiency (PE), utilization (U), and final efficiency index (EFI). We conducted a field experiment (2009-11) in southeastern Poland on Cambisols (WRB 2014). The experiment included two variables: $\mathrm{N}$ fertilization $(0,40,80$, and $120 \mathrm{~kg} / \mathrm{ha})$ and $\mathrm{S}$ fertilization (0 and $50 \mathrm{~kg} / \mathrm{ha})$.

The experiment showed the positive effect of $\mathrm{N}$ and $\mathrm{S}$ fertilization on grain and straw yields of spring wheat cv. Tybalt, with the highest yield obtained in the case of the application of $120 \mathrm{~kg} \mathrm{~N} \mathrm{ha}^{-1}$ (grain $5.59 \mathrm{t} \mathrm{ha}^{-1}$, straw $8.00 \mathrm{t} \mathrm{ha}^{-1}$ ). S fertilization increased grain yield by $3.58 \%$ and straw by $6.16 \%$. Although $\mathrm{N}$ and $\mathrm{S}$ fertilization increased content and uptake of $\mathrm{N}$ and $\mathrm{S}$ in DM, they decreased significantly on the harvest index of $\mathrm{N}$ and $\mathrm{S}\left(\mathrm{HI}_{\mathrm{N}}, \mathrm{HI}_{\mathrm{S}}\right)$. On average, $\mathrm{HI}_{\mathrm{N}}$ was $76.41 \%$ and $\mathrm{HI}_{\mathrm{S}}$ was $45.87 \%$. Among the tested combinations, the highest agronomic efficiency of $\mathrm{N}\left(\mathrm{AE}_{\mathrm{N}}\right)$, agronomic efficiency of $\mathrm{S}\left(\mathrm{AE}_{\mathrm{S}}\right)$, physiological efficiency of $\mathrm{N}\left(\mathrm{PE}_{\mathrm{N}}\right)$, physiological efficiency of $\mathrm{S}\left(\mathrm{PE}_{\mathrm{S}}\right)$, utilization of $\mathrm{N}\left(\mathrm{U}_{\mathrm{N}}\right)$, and utilization of $\mathrm{S}\left(\mathrm{U}_{\mathrm{S}}\right)$ as well the best final efficiency of $\mathrm{N}$ and $\mathrm{S}\left(\mathrm{EFI}_{\mathrm{N}}, \mathrm{EFI}_{\mathrm{S}}\right)$ were noted for the object where $\mathrm{N}$ application increased to $80 \mathrm{~kg} \mathrm{ha}^{-1}$ with the addition of $50 \mathrm{~kg} \mathrm{~S} \mathrm{ha}^{-1}$. This combination should be recommended for use in the practice of spring wheat fertilization with $\mathrm{N}$ and $\mathrm{S}$. Increasing the rate of $\mathrm{N}$ fertilizer to $120 \mathrm{~kg} \mathrm{ha}^{-1}$ caused a reduction in the utilization of $\mathrm{N}\left(\mathrm{U}_{\mathrm{N}}\right)$, and the addition of $\mathrm{S}$ to this level of $\mathrm{N}$ caused a drop in its utilization by the grain. In conclusion, $\mathrm{S}$ fertilization is necessary in the conditions of negative $\mathrm{S}$ balance in the cultivated soils.
\end{abstract}

Keywords: nitrogen, S, utilization, spring wheat

\section{Introduction}

A noticeable problem in agriculture around the world is the worsening $\mathrm{S}$ deficiency caused by an extreme tightening of environmental standards at the end of

*e-mail: hanna.klikocka@up.lublin.pl

the last century [1]. In Poland in 2010 as many as $94 \%$ of profiles tested were classified as low in $\mathrm{S}(<16.5$ $\mathrm{mg} \mathrm{SO}_{4}{ }^{2-} \mathrm{kg}^{-1}$ [2]. This situation raises the concern that the NPK fertilizer generally applied will not be balanced, and the $\mathrm{S}$ deficiency may reduce utilization of the remaining components, primarily $\mathrm{N}$.

$\mathrm{N}$ and $\mathrm{S}$ are both important constituents of protein, and adequate supplies of both nutrients are important for optimum crop yield [3-4]. S and nitrogen nutrition interact 
at many levels, as the uptake and assimilation of $\mathrm{NO}_{3}$ and $\mathrm{SO}_{4}{ }^{2-}$ have much in common, and there are many common products of $\mathrm{N}$ and $\mathrm{S}$ metabolism [5]. For assimilation of sulphate to occur, plants must contain adequate levels of this precursor, and as an amino acid its concentration is dependent on $\mathrm{N}$ nutrition [6]. An S deficiency in crop production can cause serious economic and ecological problems. Where $\mathrm{S}$ and magnesium are insufficient, the 'law of the minimum' may come into play, while intensive fertilization of crops with nitrogen can lead to a reduction in its utilization by plants [7]. This will affect the content of $\mathrm{S}$ and its primary and secondary metabolites, which play an important role in the diet and health of animals and humans [3].

The aim of our study was to evaluate the effects of spring wheat fertilization with $\mathrm{N}$ and $\mathrm{S}$ fertilizers on harvest index (HI), agronomic efficiency (AE), physiological efficiency (PE), utilization (U), and final efficiency index (EFI).

\section{Materials and Methods}

A field experiment was carried out in 2009-11 in Malice in southeastern Poland $\left(50^{\circ} 42^{\prime} \mathrm{N}, 23^{\circ} 15^{\prime} \mathrm{E}\right)$, in a randomized split-plot design with four replications. The experiment was conducted on cambisols (WRB 2014) consisting of light silty sand (sand $68 \%$, silt $31 \%$, clay $1 \%)$. The soil was slightly acidic $(\mathrm{pH}=5.6)$, with high available $\mathrm{P}$ content (mean $52.1 \mathrm{mg} \mathrm{kg}^{-1}$ ), medium content of available $\mathrm{K}$ (mean $84.5 \mathrm{mg} \mathrm{kg}^{-1}$ ), and available $\mathrm{Mg}$ (mean $34.5 \mathrm{mg} \mathrm{kg}^{-1}$ ), and low content of available $\mathrm{S}_{-} \mathrm{SO}_{4}$ (mean $12.4 \mathrm{mg} \mathrm{kg}^{-1}$ ).

The subject of the experiment was the Tybalt variety of spring wheat (Triticum aestivum L.) fertilized with different doses of $\mathrm{N}\left(0,40,80\right.$, and $\left.120 \mathrm{~kg} \mathrm{~N} \mathrm{ha}^{-1}\right)$ and $\mathrm{S}\left(0\right.$ and $\left.50 \mathrm{~kg} \mathrm{~S} \mathrm{ha}^{-1}\right)$. The area of each plot was $30 \mathrm{~m}^{2}$ $(5 \mathrm{~m} \times 6 \mathrm{~m})$. The first application of $\mathrm{N}$ (as 34\% ammonium nitrate) at a rate of $40.0 \mathrm{~kg} \mathrm{~N} \mathrm{ha}^{-1}$ was made before sowing (between 28 March and 5 April, depending on the year). In the combination of 80 and $120 \mathrm{~kg} \mathrm{~N} \mathrm{ha}^{-1}$ the second $\mathrm{N}$ application was made during the beginning of shooting (BBCH 30-31). In the combination of $120 \mathrm{~kg} \mathrm{~N} \mathrm{ha}^{-1}$ the third $\mathrm{N}$ application was made during the heading $(\mathrm{BBCH}$ 55-59). The first dose of $\mathrm{S}$ was applied before sowing (40 kg S ha') in the form of kieserite $\mathrm{MgSO}_{4} \times \mathrm{H}_{2} \mathrm{O}$ (as $15.1 \% \mathrm{Mg}, 20.0 \% \mathrm{~S}$ ), and the second $\left(10 \mathrm{~kg} \mathrm{~S} \mathrm{ha}^{-1}\right)$ as foliar application in the form of magnesium sulphate heptahydrate $\left(\mathrm{MgSO}_{4} \times 7 \mathrm{H}_{2} \mathrm{O}\right)(10.2 \% \mathrm{Mg}, 12.8 \% \mathrm{~S}$ or $\left.32 \% \mathrm{SO}_{3}\right)\left(3.2 \% \mathrm{SO}_{3}\right.$ solution in $100 \mathrm{~L}$ of water per $300 \mathrm{~L}$ water per ha) in the beginning of shooting $(\mathrm{BBCH}$ 30-31). Before sowing, in the dose $39.6 \mathrm{~kg} \mathrm{P} \mathrm{ha}^{-1}$ (as $17.4 \%$ granular triple superphosphate) and $\mathrm{K}$ in the dose $83 \mathrm{~kg} \mathrm{~K} \mathrm{ha}^{-1}$ (as $49.8 \%$ potassium salt) were applied. More detailed data on meteorological conditions and protection of the spring wheat plants against pests in the experimental stand can be found in Klikocka et al. [8].

Grain yield and straw (at 11\% moisture content) was calculated after the harvest $(\mathrm{BBCH} 92)$ from each plot. In dry matter (DM) of grain and straw the content of total $\mathrm{N}$ and total $\mathrm{S}\left(\mathrm{g} \mathrm{kg}^{-1} \mathrm{DM}\right)$ was determined with a LECO CNS-2000 analyser. Content of S was determined by infrared spectrometry (DIN ISO 15178:2001) and $\mathrm{N}$ in a differential thermal conductivity detector (DIN ISO 13878:1998). Nutrient uptake by the grain and straw was calculated as the product of the $\mathrm{N}$ and $\mathrm{S}$ content and grain and straw yield of spring wheat, respectively.

The efficiency of fertilization and utilization of nitrogen and $\mathrm{S}$ by the spring wheat was calculated for average samples as follows:

A. Agronomic efficiency $\left(\mathrm{AE}_{\mathrm{N} \text { or } \mathrm{S}}\right)$ expressed in $\mathrm{kg} / \mathrm{kg}$, which is the ratio of the increase in yield due to fertilization with $\mathrm{N}$ and $\mathrm{S}$ (yield at $\mathrm{N}_{\mathrm{x}}-$ yield at $\mathrm{N}_{0}$ ) to the $\mathrm{N}$ and $\mathrm{S}$ fertilizer-applied $\mathrm{N}_{\mathrm{x}}$

B. Physiological efficiency $\left(\mathrm{PE}_{\mathrm{N} \text { or S }}\right)$ expressed in $\mathrm{kg} / \mathrm{kg}$, which is the ratio of the increase in yield due to fertilization with $\mathrm{N}$ and $\mathrm{S}$ (yield for $\mathrm{N}_{\mathrm{x}}$ - yield for $\mathrm{N}_{0}$ ) to the increase in $\mathrm{N}$ and $\mathrm{S}$ accumulation (accumulation at $\mathrm{N}_{\mathrm{x}}$ - accumulation at $\mathrm{N}_{0}$ )

C. Utilization of $\mathrm{N}$ and $\mathrm{S}\left(\mathrm{U}_{\mathrm{N} \text { or } \mathrm{S}}\right)$ - expressed as a percentage, calculated from the quotient of agronomic efficiency divided by physiological efficiency

D. Final efficiency index $\left(\mathrm{EFI}_{\mathrm{N} \text { or } \mathrm{S}}\right)$ - expressed in PLN, which is the increase in yield in PLN per PLN spent on fertilizer

E. Harvest index of $\mathrm{N}$ and $\mathrm{S}\left(\mathrm{HI}_{\mathrm{N} \text { or } \mathrm{S}}\right)$ - expressed as a percentage, the ratio of the amount of $\mathrm{N}$ or $\mathrm{S}$ in the wheat grain to the total amount of $\mathrm{N}$ or $\mathrm{S}$ in the plant. Analysis of variance was performed by Snedecor's F-test. Significance of differences was calculated using Tukey's test $(p=0.05)$ followed by post-hoc analysis. The statistical software Excel 7.0 and Statistica (StatSoft Polska'97) were used for analysis.

\section{Results and Discussion}

Analysis of the results showed a significant beneficial effect of $\mathrm{N}$ and $\mathrm{S}$ fertilizer on the grain and straw yield of spring wheat and on most of the agro-economical characteristics. For grain yield and studied characteristics no interaction was found between increasing application rates of $\mathrm{N}$ and $\mathrm{S}$. However, the addition of $\mathrm{S}$ to each dose of $\mathrm{N}$ independently increased yield and a number of other features. This type of yield-increasing factor, in this case fertilizer, signals the additive effect of S. This type of reaction is manifested in conditions in which the deficiency of the nutrient is small, which is consistent with the law of diminishing returns (also known as Mitscherlich's Law) [9].

The experiment showed a positive effect of $\mathrm{N}$ and $\mathrm{S}$ application on grain yield of spring wheat with the highest yield obtained in the case of the application of $80 \mathrm{~kg} \mathrm{~N} \mathrm{ha}^{-1}$ $\left(5.40 \mathrm{t} \mathrm{ha}^{-1}\right)$ and $120 \mathrm{~kg} \mathrm{~N} \mathrm{ha}^{-1}\left(5.59 \mathrm{t} \mathrm{ha}^{-1}\right)$ - an increase in the average $1.42 \mathrm{tha}^{-1}(34.7 \%)$ with respect to the control. This is consistent in accordance with observations of Ercoli et al. [10]. 


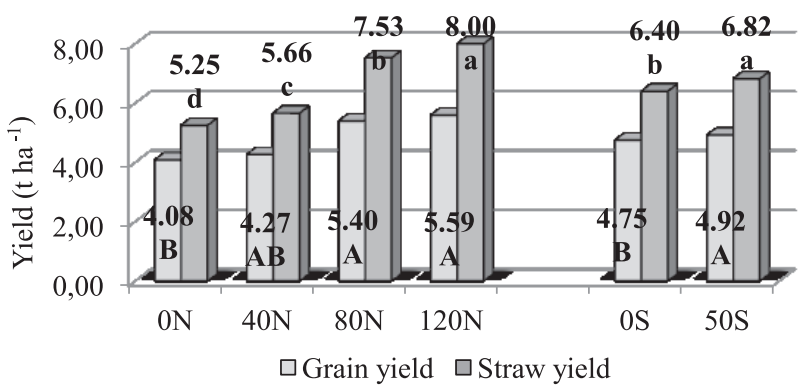

Fig. 1. Effect of nitrogen and sulphur fertilization as well as study year on grain and straw yields of spring wheat.

Values with different letters in the column differ significantly $(\mathrm{P}<0.05)$.

$\mathrm{S}$ fertilization increased grain yield by $3.58 \%$. The straw yield increased proportionally as the $\mathrm{N}$ application rate increased (Fig. 1). According to Potarzycki [11], the use of fertilizers containing sulfur affects the greater the accumulation of $\mathrm{N}$ in the grain. In a study by Podleśna [12], $\mathrm{S}$ fertilization of winter wheat at a rate of $60 \mathrm{~kg} \mathrm{~S} \mathrm{ha}^{-1}$ led to an increase in grain yield of $11 \%$. In the presented research the content and uptake of nitrogen by the spring wheat grain significantly increased in direct proportion to the increase in the $\mathrm{N}$ application rate and was the highest following the application of $120 \mathrm{~kg} \mathrm{~N} \mathrm{ha}^{-1}$ ( $\mathrm{N}$ content of $28.59 \mathrm{~g} \mathrm{~kg}^{-1} \mathrm{DM}$ and $\mathrm{N}$ uptake of $\left.141.5 \mathrm{~kg} \mathrm{ha}^{-1}\right)$. The content of $\mathrm{N}$ in the spring wheat straw significantly increased to the rate of $80 \mathrm{~kg} \mathrm{~N} \mathrm{ha}^{-1}$. However, the highest content and uptake of $\mathrm{N}$ by straw was found after the application of $120 \mathrm{~kg} \mathrm{~N} \mathrm{ha}^{-1}$ ( $\mathrm{N}$ content of $6.50 \mathrm{~g} \mathrm{~kg}^{-1} \mathrm{DM}$ and $\mathrm{N}$ uptake of $46.1 \mathrm{~kg} \mathrm{ha}^{-1}$ ). Also, Knapowski et al. [13] significantly had the highest $\mathrm{N}$ content in the triticale grain after the application of the highest $\mathrm{N}$ dose, i.e., $120 \mathrm{~kg} \mathrm{ha}^{-1}$, and this was higher compared to the object fertilized with $80 \mathrm{~kg}$ $\mathrm{N} \mathrm{ha}^{-1}$ by $1.1 \mathrm{~g} \mathrm{~N} \mathrm{~kg}^{-1} \mathrm{DM}$. The nitrogen application at the rates of 80 and $120 \mathrm{~kg} \mathrm{~N}^{-1}$ decreased $\mathrm{HI}_{\mathrm{N}}$ significantly in relation to control, and to the lowest rate (i.e., $40 \mathrm{~kg} \mathrm{ha}^{-1}$ ). Similarly, Flood and Martin [14] indicate a positive correlation between wheat grain yield and $\mathrm{N}$ harvest index and a negative correlation between the content of $\mathrm{N}$ in the grain and $\mathrm{HI}_{\mathrm{N}}$. According to Bänziger [15], the content of total $\mathrm{N}$ in the grain correlates positively with the $\mathrm{N}$ harvest index. The response of wheat to $\mathrm{N}$ is in accordance with several such reports available in literature [5]. The addition of $\mathrm{S}$ to $\mathrm{N}$ application significantly increased the yield of grain and straw, the content and uptake of $\mathrm{N}$, and the decrease of $\mathrm{HI}_{\mathrm{N}}$ (Table 1). Also in studies of Podleśna et al. [16], $S$ fertilization increased the $\mathrm{N}$ index harvest compared to objects without S. Similarly, a response to $S$ fertilization has been reported by a number of researchers [17-19]. Przygocka-Cyna and Grzebisz [20$21]$ indicate that $\mathrm{S}$ fertilization can lead to a reduction in $\mathrm{N}$ content in the grain as a result of the grain yield increase, and described the phenomenon as the effect of dilution. Meanwhile, Barczak [22] showed that S fertilization resulted in an increase in the content of total $\mathrm{N}$ in spring barley. Also in studies of Martin [23] and Reussi et al. [24], the increasing level of sulfur increased noticeably the $\mathrm{N}$ content in grains of wheat.

The content and uptake of S by the spring wheat grain significantly increased together with the $\mathrm{N}$ application rate increase and were highest following the application

Table 1 . Content and uptake of $\mathrm{N}$ by spring wheat (mean of three years).

\begin{tabular}{|c|c|c|c|c|c|c|c|}
\hline \multirow{2}{*}{\multicolumn{2}{|c|}{$\mathrm{S}$ and $\mathrm{N}$ treatment }} & \multicolumn{2}{|c|}{$\mathrm{N}$ content $\left(\mathrm{g} \mathrm{kg}^{-1} \mathrm{DM}\right)$} & \multicolumn{3}{|c|}{$\mathrm{N}$ uptake $\left(\mathrm{g} \mathrm{ha}^{-1}\right)$} & \multirow{3}{*}{$\begin{array}{c}\begin{array}{c}\mathrm{N} \text { harvest index } \\
(\%)\end{array} \\
78.50 \mathrm{a}\end{array}$} \\
\hline & & \multirow{2}{*}{$\frac{\text { Grain }}{25.40 \mathrm{a}}$} & \multirow{2}{*}{$\frac{\text { Straw }}{5.51 \mathrm{a}}$} & \multirow{2}{*}{$\frac{\text { Grain }}{90.3 \mathrm{a}}$} & \multirow{2}{*}{$\frac{\text { Straw }}{24.8 \mathrm{a}}$} & \multirow{2}{*}{$\begin{array}{c}\text { Total } \\
115.1 \mathrm{a}\end{array}$} & \\
\hline \multirow{4}{*}{$\begin{array}{c}0 \mathrm{~S} \\
(\mathrm{~N} \times \mathrm{S})\end{array}$} & 0 & & & & & & \\
\hline & 40 & $26.88 \mathrm{a}$ & $5.89 \mathrm{a}$ & $98.4 \mathrm{a}$ & $28.5 \mathrm{a}$ & $126.9 \mathrm{a}$ & $77.53 \mathrm{a}$ \\
\hline & 80 & $27.69 \mathrm{a}$ & $6.58 \mathrm{a}$ & $131.2 \mathrm{a}$ & $42.0 \mathrm{a}$ & $173.2 \mathrm{a}$ & $75.80 \mathrm{a}$ \\
\hline & 120 & $28.40 \mathrm{a}$ & $6.51 \mathrm{a}$ & $137.3 \mathrm{a}$ & $45.6 \mathrm{a}$ & $183.0 \mathrm{a}$ & $75.07 \mathrm{a}$ \\
\hline \multirow{4}{*}{$\begin{array}{c}50 \mathrm{~S} \\
(\mathrm{~N} \times \mathrm{S})\end{array}$} & 0 & $25.61 \mathrm{a}$ & $5.74 \mathrm{a}$ & $93.1 \mathrm{a}$ & $27.9 \mathrm{a}$ & $120.9 \mathrm{a}$ & $77.03 \mathrm{a}$ \\
\hline & 40 & $27.58 \mathrm{a}$ & $6.02 \mathrm{a}$ & $106.6 \mathrm{a}$ & $31.1 \mathrm{a}$ & $137.8 \mathrm{a}$ & $74.23 \mathrm{a}$ \\
\hline & 80 & $27.81 \mathrm{a}$ & $6.65 \mathrm{a}$ & $133.6 \mathrm{a}$ & $46.3 \mathrm{a}$ & $179.9 \mathrm{a}$ & $74.23 \mathrm{a}$ \\
\hline & 120 & $28.78 \mathrm{a}$ & $6.48 \mathrm{a}$ & $145.6 \mathrm{a}$ & $46.7 \mathrm{a}$ & $192.2 \mathrm{a}$ & $75.73 \mathrm{a}$ \\
\hline $\begin{array}{c}0 \mathrm{~S} \\
50 \mathrm{~S}\end{array}$ & $\begin{array}{l}\text { Mean } \\
(\mathrm{S})\end{array}$ & $\begin{array}{l}37.09 \mathrm{~B} \\
37.44 \mathrm{~A}\end{array}$ & $\begin{array}{l}6.13 \mathrm{~A} \\
6.23 \mathrm{~A}\end{array}$ & $\begin{array}{l}114.3 \mathrm{~B} \\
119.7 \mathrm{~A}\end{array}$ & $\begin{array}{l}35.2 \mathrm{~B} \\
38.0 \mathrm{~A}\end{array}$ & $\begin{array}{l}149.5 \mathrm{~B} \\
157.7 \mathrm{~A}\end{array}$ & $\begin{array}{l}76.73 \mathrm{~A} \\
76.10 \mathrm{~B}\end{array}$ \\
\hline \multirow{4}{*}{$\begin{array}{c}\text { Mean } \\
(\mathrm{N})\end{array}$} & $0 \mathrm{~N}$ & $25.50 \mathrm{C}$ & $5.63 \mathrm{~B}$ & $91.7 \mathrm{D}$ & $26.3 \mathrm{C}$ & $118.0 \mathrm{D}$ & $77.77 \mathrm{~A}$ \\
\hline & $40 \mathrm{~N}$ & $27.23 \mathrm{~B}$ & $5.96 \mathrm{AB}$ & $102.5 \mathrm{C}$ & $29.8 \mathrm{~B}$ & $132.3 \mathrm{C}$ & $77.47 \mathrm{~A}$ \\
\hline & $80 \mathrm{~N}$ & $27.75 \mathrm{~B}$ & $6.62 \mathrm{~A}$ & $132.4 \mathrm{~B}$ & $44.1 \mathrm{~A}$ & 176.6 B & $75.02 \mathrm{~B}$ \\
\hline & $120 \mathrm{~N}$ & $28.59 \mathrm{~A}$ & $6.50 \mathrm{~A}$ & $141.5 \mathrm{~A}$ & $46.1 \mathrm{~A}$ & $187.6 \mathrm{~A}$ & $75.40 \mathrm{~B}$ \\
\hline
\end{tabular}

Values with different letters in the column differ significantly $(\mathrm{P}<0.05)$. 
Table 2. Content and uptake of S by spring wheat (mean of three years)

\begin{tabular}{|c|c|c|c|c|c|c|c|}
\hline \multirow{2}{*}{\multicolumn{2}{|c|}{$\mathrm{S}$ and $\mathrm{N}$ treatment }} & \multicolumn{2}{|c|}{ S content $\left(\mathrm{g} \mathrm{kg}^{-1} \mathrm{DM}\right)$} & \multicolumn{3}{|c|}{ S uptake $\left(\mathrm{g} \mathrm{ha}^{-1}\right)$} & \multirow{3}{*}{$\begin{array}{c}\text { S harvest index } \\
(\%)\end{array}$} \\
\hline & & \multirow{2}{*}{$\begin{array}{c}\text { Grain } \\
1.24 \mathrm{a}\end{array}$} & \multirow{2}{*}{$\begin{array}{l}\text { Straw } \\
1.08 \mathrm{a}\end{array}$} & \multirow{2}{*}{$\frac{\text { Grain }}{4.44 \mathrm{a}}$} & \multirow{2}{*}{$\frac{\text { Straw }}{4.85 \mathrm{a}}$} & \multirow{2}{*}{$\begin{array}{c}\text { Total } \\
9.28 \mathrm{a}\end{array}$} & \\
\hline \multirow{4}{*}{$\begin{array}{c}0 \mathrm{~S} \\
(\mathrm{~N} \times \mathrm{S})\end{array}$} & 0 & & & & & & \\
\hline & 40 & $1.24 \mathrm{a}$ & $1.10 \mathrm{a}$ & $4.56 \mathrm{a}$ & $5.36 \mathrm{a}$ & $9.91 \mathrm{a}$ & $45.93 \mathrm{a}$ \\
\hline & 80 & $1.33 \mathrm{a}$ & $1.25 \mathrm{a}$ & $5.99 \mathrm{a}$ & $7.97 \mathrm{a}$ & $14.29 \mathrm{a}$ & $44.23 \mathrm{a}$ \\
\hline & 120 & $1.37 \mathrm{a}$ & $1.12 \mathrm{a}$ & $6.64 \mathrm{a}$ & $7.86 \mathrm{a}$ & $15.40 \mathrm{a}$ & $45.80 \mathrm{a}$ \\
\hline \multirow{4}{*}{$\begin{array}{c}50 \mathrm{~S} \\
(\mathrm{~N} \times \mathrm{S})\end{array}$} & 0 & $1.25 \mathrm{a}$ & $1.10 \mathrm{a}$ & $4.60 \mathrm{a}$ & $5.33 \mathrm{a}$ & $9.92 \mathrm{a}$ & $46.23 \mathrm{a}$ \\
\hline & 40 & $1.28 \mathrm{a}$ & $1.12 \mathrm{a}$ & $4.96 \mathrm{a}$ & $5.81 \mathrm{a}$ & $10.76 \mathrm{a}$ & $46.00 \mathrm{a}$ \\
\hline & 80 & $1.34 \mathrm{a}$ & $1.18 \mathrm{a}$ & $6.44 \mathrm{a}$ & $8.20 \mathrm{a}$ & $14.64 \mathrm{a}$ & $44.00 \mathrm{a}$ \\
\hline & 120 & $1.40 \mathrm{a}$ & $1.18 \mathrm{a}$ & $7.09 \mathrm{a}$ & $8.48 \mathrm{a}$ & $15.57 \mathrm{a}$ & $45.47 \mathrm{a}$ \\
\hline $\begin{array}{c}0 \mathrm{~S} \\
50 \mathrm{~S}\end{array}$ & $\begin{array}{l}\text { Mean } \\
(\mathrm{S})\end{array}$ & $\begin{array}{l}1.30 \mathrm{~B} \\
1.32 \mathrm{~A}\end{array}$ & $\begin{array}{l}1.14 \mathrm{~A} \\
1.14 \mathrm{~A}\end{array}$ & $\begin{array}{l}5.41 \mathrm{~B} \\
5.77 \mathrm{~A}\end{array}$ & $\begin{array}{l}6.51 \mathrm{~A} \\
6.96 \mathrm{~A}\end{array}$ & $\begin{array}{l}12.00 \mathrm{~B} \\
12.73 \mathrm{~A}\end{array}$ & $\begin{array}{l}46.31 \mathrm{~A} \\
45.43 \mathrm{~B}\end{array}$ \\
\hline \multirow{4}{*}{$\begin{array}{c}\text { Mean } \\
(\mathrm{N})\end{array}$} & $0 \mathrm{~N}$ & $1.25 \mathrm{C}$ & $1.09 \mathrm{BC}$ & $4.52 \mathrm{BC}$ & $5.09 \mathrm{~B}$ & $9.60 \mathrm{~B}$ & $47.75 \mathrm{~A}$ \\
\hline & $40 \mathrm{~N}$ & $1.26 \mathrm{C}$ & $1.11 \mathrm{BC}$ & $4.76 \mathrm{C}$ & $5.58 \mathrm{~B}$ & $10.34 \mathrm{~B}$ & $45.97 \mathrm{~B}$ \\
\hline & $80 \mathrm{~N}$ & $1.34 \mathrm{~B}$ & $1.21 \mathrm{~A}$ & $6.21 \mathrm{~B}$ & $8.09 \mathrm{~A}$ & $14.47 \mathrm{~A}$ & $44.12 \mathrm{BC}$ \\
\hline & $120 \mathrm{~N}$ & $1.39 \mathrm{~A}$ & $1.15 \mathrm{~B}$ & $6.87 \mathrm{~A}$ & $8.17 \mathrm{~A}$ & $15.04 \mathrm{~A}$ & $45.63 \mathrm{~B}$ \\
\hline
\end{tabular}

Values with different letters in the column differ significantly $(\mathrm{P}<0.05)$.

of $120 \mathrm{~kg} \mathrm{~N} \mathrm{ha}^{-1}$ (S content $-1.39 \mathrm{~g} \mathrm{~kg}^{-1} \mathrm{DM}$ and $\mathrm{S}$ uptake $\left.-6.87 \mathrm{~kg} \mathrm{ha}^{-1}\right)$. The content of $\mathrm{S}$ in the straw of spring wheat significantly increased to the rate of $80 \mathrm{~kg} \mathrm{~N}^{-1}$ (1.21 $\left.\mathrm{g} \mathrm{kg}^{-1} \mathrm{DM}\right)$. Although the uptake of $\mathrm{S}$ by straw also significantly increased to the rate of $80 \mathrm{~kg} \mathrm{~N} \mathrm{ha}^{-1}$, the highest uptake of $\mathrm{S}$ by straw was found after the application of $120 \mathrm{~kg} \mathrm{~N} \mathrm{ha}^{-1}\left(\mathrm{~S}-8.17 \mathrm{~kg} \mathrm{ha}^{-1}\right)$. Howarth et al. [25] concludes that $\mathrm{N}$ deficiency caused a slower accumulation of $\mathrm{N}$ and $\mathrm{S}$ in grain, which resulted in lower final content of these elements. A study by Potarzycki [7] showed that spring barley well nourished by $\mathrm{S}$ is characterized by a lower $\mathrm{N}$ content in the straw. On the other hand, Gondek and Gondek [26] showed that spring wheat fertilization with $\mathrm{S}$ resulted in a significant increase in $\mathrm{N}$ content in the straw compared with control. Howarth et al. [25] concludes that $\mathrm{S}$ fertilization increased uptake of $\mathrm{S}$ by grain of 29.8\%. In studies of Monaghan et al. [27], wheat grain accumulated to $50 \%$ of the total amount of $\mathrm{S}$ taken by biomass plant. According to the Kovar and Grant [28], $\mathrm{S}$ content of grain is generally higher than in vegetative tissue of plants and also the contents of the elements in the plants vary depending on its development phase [29]. The $\mathrm{N}$ application at each rate and the addition of $\mathrm{S}$ to $\mathrm{N}$ decreased significantly the $\mathrm{S}$ harvest index $\left(\mathrm{HI}_{\mathrm{S}}\right)$. Although the addition of $\mathrm{S}$ to $\mathrm{N}$ application significantly increased the $\mathrm{S}$ content and its uptake by grain and total $\mathrm{S}$ uptake (grain + straw), there is no impact on these parameters of straw (Table 2). A study led by Fotyma [30] on fertilization of spring wheat with $\mathrm{S}$ showed that the application of 60 $\mathrm{kg} \mathrm{S} \mathrm{ha-1} \mathrm{increased} \mathrm{grain} \mathrm{yield} \mathrm{and} \mathrm{N}$ uptake, but did not affect the accumulation of $\mathrm{S}$ in the grain. Fotyma [30] claims that $\mathrm{S}$ indirectly increases crop yield by influencing $\mathrm{N}$ transformation in the plant. Podleśna [12] emphasizes that the application of S in fertilization of spring wheat and rapeseed had a beneficial effect on grain and seed yield by contributing to the appropriate content of $\mathrm{S}$ and $\mathrm{N}$, the correct development of aerial parts, and the formation of the root system. Moreover, Podleśna [12] showed that $\mathrm{N}$ uptake was dependent on efficient $\mathrm{S}$ fertilization. Reussi et al. [24] say that $\mathrm{S}$ and $\mathrm{N}$ interact on their concentration in plants and the total accumulation in yields, as the $S$ content in the grain of wheat depends not only on its dose, but also on the availability of $\mathrm{N}$. The interaction of these elements at the level of the many metabolic processes is reflected in the growth and development of crops, which ultimately affects the level and quality of their yield.

In another study Fotyma [31] stated that the effectiveness of nitrogen can be evaluated using such indicators as agricultural efficiency and physiological efficiency. These indicators allow us to determine the ability of plants to process downloaded $\mathrm{N}$ on yield. According to Rutkowska [32], both of these indicators reach the largest values in a range of small doses of fertilizer and decrease with the level of fertilization. It was similar in the presented research. The application of $40 \mathrm{~kg} \mathrm{~N} \mathrm{ha}^{-1}$, in comparison with the control (without $\mathrm{N}$ ), caused an increase in the grain yield of the spring wheat of $2.9 \mathrm{~kg}$ per $\mathrm{kg} \mathrm{N}$ applied in the fertilizer. Increasing the $\mathrm{N}$ application rate to $80 \mathrm{~kg} \mathrm{ha}^{-1}$ caused an increase in the grain to reach $16.6 \mathrm{~kg}$ per $\mathrm{kg} \mathrm{N}$, while the rate of $120 \mathrm{~kg}$ $\mathrm{N} \mathrm{ha}^{-1}$ reduced the increase to $12.0 \mathrm{~kg}$ per $\mathrm{kg}$ of $\mathrm{N}$ (Table 3, Fig. 2). The greatest increase in grain per $\mathrm{kg}$ applied $\mathrm{N}$ was observed where the application rate was increased from 40 to $80 \mathrm{~kg} \mathrm{~N} \mathrm{ha}^{-1}$, and it amounted $30.4 \mathrm{~kg}$ grain per $\mathrm{kg}$ $\mathrm{N}$ (Table 3). The addition of $\mathrm{S}$ to the lowest $\mathrm{N}$ application rate, $40 \mathrm{~kg} \mathrm{~N} \mathrm{ha}^{-1}$, caused an increase in grain of $8.8 \mathrm{~kg}$ 
Table 3. The indicators of N-S fertilization efficiency (mean three years)

\begin{tabular}{|c|c|c|c|c|c|c|c|c|c|}
\hline \multirow{2}{*}{\multicolumn{2}{|c|}{$\begin{array}{l}\text { Fertilizing combinations: } \\
\text { nitrogen and sulphur }\end{array}$}} & \multicolumn{2}{|c|}{$\begin{array}{l}\text { Efficiency of } \mathrm{N} \\
\text { fertilization }\end{array}$} & \multicolumn{2}{|c|}{$\begin{array}{l}\text { Efficiency of S } \\
\text { fertilization }\end{array}$} & \multicolumn{2}{|c|}{$\begin{array}{c}\text { Utilization } \\
(\%)\end{array}$} & \multicolumn{2}{|c|}{$\begin{array}{l}\text { Final efficiency } \\
\text { index } * * *\end{array}$} \\
\hline & & $* \mathrm{AE}_{\mathrm{N}}$ & $* * \mathrm{PE}_{\mathrm{N}}$ & $* \mathrm{AE}_{\mathrm{S}}$ & $* * \mathrm{PE}_{\mathrm{S}}$ & $\mathrm{U}_{\mathrm{N}}$ & $\mathrm{U}_{\mathrm{s}}$ & $\mathrm{EFI}_{\mathrm{N}}$ & $\mathrm{EFI}_{\mathrm{S}}$ \\
\hline \multirow{6}{*}{$\mathrm{N}$} & $0-40$ & 2.9 & 14.3 & & 972 & 20.2 & & 0.7 & \\
\hline & $0-80$ & 16.6 & 32.5 & & 707 & 51.2 & & 3.9 & \\
\hline & $0-120$ & 12.0 & 30.6 & & 652 & 39.2 & & 4.0 & \\
\hline & $40-80$ & 30.4 & 37.0 & & 689 & 82.2 & & 7.1 & \\
\hline & $40-120$ & 16.5 & 34.0 & & 634 & 48.7 & & 5.6 & \\
\hline & $80-120$ & 2.7 & 17.1 & & 333 & 39.2 & & 4.0 & \\
\hline \multirow{7}{*}{$\mathrm{N} \times \mathrm{S}$} & $0-0+S$ & & & 2.1 & 645 & & 0.3 & & 0.3 \\
\hline & $0-40+S$ & 8.8 & 21.6 & 7.0 & 676 & 40.8 & 1.0 & 4.9 & 2.2 \\
\hline & $0-80+\mathrm{S}$ & 17.5 & 32.4 & 28.0 & 700 & 54.1 & 4.0 & 5.8 & 5.4 \\
\hline & $0-120+\mathrm{S}$ & 14.0 & 30.0 & 33.7 & 635 & 46.0 & 5.3 & 4.5 & 6.2 \\
\hline & $40-80+\mathrm{S}$ & 32.1 & 36.0 & 25.7 & 683 & 88.0 & 3.8 & 11.0 & 5.1 \\
\hline & $40-120+S$ & 19.6 & 33.0 & 31.4 & 619 & 59.0 & 5.1 & 6.4 & 5.9 \\
\hline & $80-120+S$ & 8.9 & 24.2 & 7.1 & 459 & 35.8 & 1.5 & 5.8 & 2.7 \\
\hline \multirow{3}{*}{$\mathrm{S}$} & $40+S-80+S$ & 26.2 & 38.9 & & 709 & 67.4 & & 9.6 & \\
\hline & $40+\mathrm{S}-120+\mathrm{S}$ & 16.7 & 34.3 & & 624 & 48.7 & & 3.9 & \\
\hline & $80+S-120+S$ & 7.2 & 23.4 & & 435 & 30.0 & & 5.4 & \\
\hline
\end{tabular}

*Agronomic efficiency $(\mathrm{AE})=1 \mathrm{~kg}$ of grain $/ 1 \mathrm{~kg}$ of a component in fertilizer;

$* *$ Physiological efficiency $(\mathrm{PE})=1 \mathrm{~kg}$ of grain $/ 1 \mathrm{~kg}$ of accumulated component;

***Final efficiency index $(\mathrm{EFI})=$ grain in PLN/ fertilizer in PLN (print prices IERGiŻ, July, 2012r.: grains of spring wheat:

1 Ton - 900 PLN, ammonium nitrate: 1 Ton - 1,390 PLN, kieserite: 1 Ton - 1,340 PLN, epsomite: 1 Ton - 1,200 PLN)

per $\mathrm{kg} \mathrm{N}$, which was a threefold increase in agronomic efficiency of $\mathrm{N}\left(\mathrm{AE}_{\mathrm{N}}\right)$ in comparison with the variant without S. Among the combinations tested, the greatest $\mathrm{AE}_{\mathrm{N}}$ was noted in the case of $40 \mathrm{~N}-80 \mathrm{~N}+50$ S, i.e., the increase in $\mathrm{N}$ fertilization to $80 \mathrm{~kg} \mathrm{ha}^{-1}$ with the addition of $\mathrm{S}$ increased the grain in the amount of $32.1 \mathrm{~kg}$ per $\mathrm{kg}$ $\mathrm{N}$ with $\mathrm{S}$. This is also confirmed by the combination $40 \mathrm{~N}+50 \mathrm{~S}-80 \mathrm{~N}+50 \mathrm{~S}$, where an increase in grain of $26.2 \mathrm{~kg}$ per $\mathrm{kg}$ of applied nitrogen with $\mathrm{S}$ addition was obtained. The application of $\mathrm{S}$ in the control (without $\mathrm{N}$ ) caused an increase in spring wheat grain as $2.1 \mathrm{~kg}$ per $\mathrm{kg}$ applied $\mathrm{S}$ fertilizer. The addition of $\mathrm{N}$ caused a directly proportional increase in grain as the application rate increased; it was highest following the application of $120 \mathrm{~kg} \mathrm{~N} \mathrm{ha}^{-1}: 33.7 \mathrm{~kg}$ per $\mathrm{kg}$ of S applied in the fertilizer. Potarzycki [11] claimed that $\mathrm{S}$ fertilization increased agricultural efficiency (agronomic) of $\mathrm{N}$ fertilizer.

Physiological efficiency (PE) showed a similar pattern to that of agronomic efficiency (AE). In the case of $\mathrm{N}$, the increase in spring wheat grain per $\mathrm{kg}$ of accumulated $\mathrm{N}$ was at the application rate of 40 and $80 \mathrm{~kg} \mathrm{~N} \mathrm{ha}^{-1}$, in comparison to the control, while the application of $\mathrm{N}$ at a rate of $120 \mathrm{~kg} \mathrm{ha}^{-1}$ reduced the increase of accumulated $\mathrm{N}$ (Table 3, Fig. 2). The addition of $\mathrm{S}$ to the lowest $\mathrm{N}$ application rate, $40 \mathrm{~kg} \mathrm{ha}^{-1}$, caused a grain increase of $21.6 \mathrm{~kg}$ per $\mathrm{kg}$ of accumulated $\mathrm{N}$, which was a 1.5 - fold increase in the physiological efficiency of $\mathrm{N}\left(\mathrm{PE}_{\mathrm{N}}\right)$ in comparison to the variant without $\mathrm{S}$. This means that $\mathrm{S}$ increased the physiological efficiency of $\mathrm{N}$ uptake by the spring wheat grain one and a half times. The physiological efficiency of the effect of $\mathrm{S}\left(\mathrm{PE}_{\mathrm{S}}\right)$ alone, without taking $\mathrm{N}$ into account (control), was very high, as $1 \mathrm{~kg}$ of accumulated $\mathrm{S}$ caused an increase in spring wheat grain by $645.4 \mathrm{~kg}$. The application of $\mathrm{N}$ and $\mathrm{S}$ together caused the physiological efficiency of $\mathrm{S}\left(\mathrm{PE}_{\mathrm{S}}\right)$ to increase by $4.8 \%$ and $8.5 \%$ for the application of 40 and $80 \mathrm{~kg}$ $\mathrm{N} \mathrm{ha}^{-1}$, respectively, while the addition of $\mathrm{S}$ to $120 \mathrm{~kg}$ $\mathrm{N} \mathrm{ha}^{-1}$ caused a decrease in the physiological efficiency of $\mathrm{S}\left(\mathrm{PE}_{\mathrm{S}}\right)$ in comparison to all other combinations tested. The physiological efficiency of $\mathrm{S}\left(\mathrm{PE}_{\mathrm{S}}\right)$ calculated in the control variant, in conditions of natural soil without $\mathrm{N}$ and $\mathrm{S}$ fertilizer, was $972.2 \mathrm{~kg}$ of grain per $\mathrm{kg}$ of accumulated $\mathrm{S}$, and then each addition of $\mathrm{N}$ fertilizer caused a decrease in the effect of $\mathrm{S}$ on grain yield (Table 3, Fig. 2). In the studies of Fotyma [31] these indicators of $\mathrm{N}$ had higher values after the application of $\mathrm{S}$ fertilizer.

The highest utilization of $\mathrm{N}\left(\mathrm{U}_{\mathrm{N}}\right)$ by spring wheat was obtained following the application of $80 \mathrm{~kg} \mathrm{~N} \mathrm{ha}^{-1}$ (51.2\%), and the most beneficial option was the increase from 40 to $80 \mathrm{~kg} \mathrm{ha}^{-1}(82.2 \%)$. The highest application rate of $120 \mathrm{~kg} \mathrm{~N}^{-1}$ caused a decrease in utilization of $\mathrm{N}\left(\mathrm{U}_{\mathrm{N}}\right)$. The low utilization of $\mathrm{N}\left(\mathrm{U}_{\mathrm{N}}\right)$ following the application 
$\mathrm{N}$ - agronomic efficiency

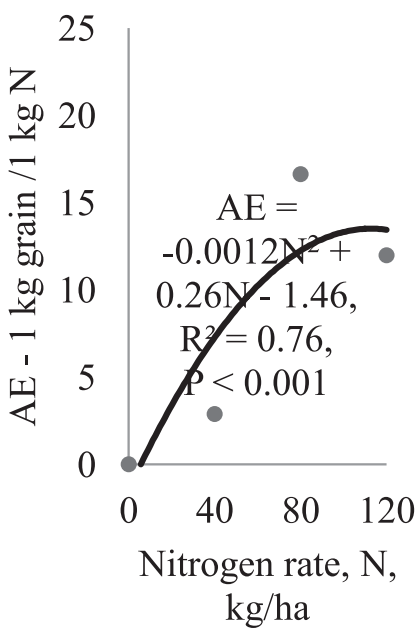

\section{N - Physiological efficiency}

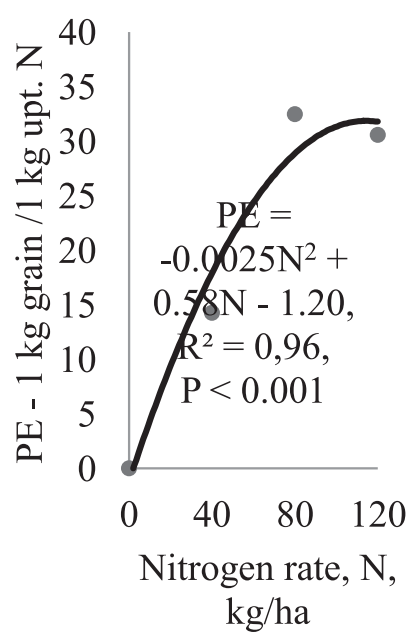

\section{S - Physiological efficiency}

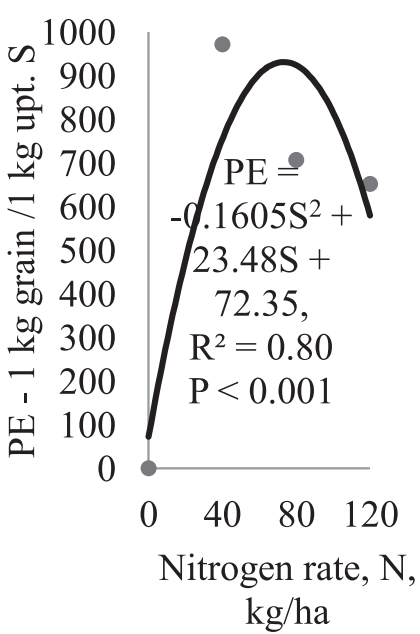

Fig. 2. The influence of $\mathrm{N}$ fertilization on agronomic (AE) and physiological efficiency (PE) of nitrogen and sulphur in spring wheat production $(n=4)$.

of $40 \mathrm{~kg} \mathrm{ha}^{-1}(20.2 \%)$ may indicate that the $\mathrm{N}$ was used to improve the state of the plants and to build vegetative parts, but it was too low a dose to achieve a high yield (Table 3). The distribution of the final efficiency index of $\mathrm{N}\left(\mathrm{EFI}_{\mathrm{N}}\right)$ was similar, as it was closely correlated with the utilization of $\mathrm{N}\left(\mathrm{U}_{\mathrm{N}}\right)$ by the spring wheat grain. Zhang et al. [33] have reported that only $30-35 \%$ of the $\mathrm{N}$ from the fertilizers is used by plants. According to Hirel et al. [34], in an intensive system of agricultural production from 50 to $75 \%$ of the $\mathrm{N}$ from the fertilizer is not used for field crops. According to these authors [33-34], the unused N is the main source of nitrate pollution of the groundwater. However, the balanced fertilization is a factor that causes the increase in the level of $\mathrm{N}$ utilization by crops.

The utilization of $\mathrm{S}\left(\mathrm{U}_{\mathrm{S}}\right)$ in the control, without $\mathrm{N}$ fertilizer, was $0.3 \%$ and increased to $5.3 \%$, in direct proportion following the application of $120 \mathrm{~kg} \mathrm{~N} \mathrm{ha}^{-1}$. This indicates that $\mathrm{N}$ increases $\mathrm{S}$ uptake and vice versa, but only the proper N:S ratio supplied to plants. In the case of the highest application rate of $120 \mathrm{~kg} \mathrm{~N} \mathrm{ha}^{-1}$ supplemented with $\mathrm{S}$, the utilization of $\mathrm{S}\left(\mathrm{U}_{\mathrm{S}}\right)$ was only $1.6 \%$ in comparison to the $80 \mathrm{~kg} \mathrm{~N}^{-1}$ variant. This case as well as the final efficiency index of $\mathrm{S}\left(\mathrm{EFI}_{\mathrm{S}}\right)$ were closely correlated with the utilization of $\mathrm{S}\left(\mathrm{U}_{\mathrm{S}}\right)$ by the spring wheat grain. Potarzycki [35] reports that the utilization of $\mathrm{N}$ by spring barley and the agronomic efficiency of $\mathrm{N}$ fertilization depended on $\mathrm{S}$ fertilization. Also, Salvagiotti et al. [36] are of the opinion that $\mathrm{S}$ fertilization increases the use of $\mathrm{N}$ from fertilizers. Szczepaniak [7] concluded that magnesium and phosphorus in maize tissues are at physiological maturity. Utilization of S by plants cultivated in the control (N0) was $0.32 \%$ and increased to $5.31 \%$ after the application of $120 \mathrm{~kg} \mathrm{~N} \mathrm{ha}^{-1}$. This indicates that $\mathrm{N}$ also assists $\mathrm{S}$ uptake and vice versa, but only to a certain point, as in the case of the highest rate of $120 \mathrm{~kg} \mathrm{~N} \mathrm{ha}^{-1}$ supplemented with $\mathrm{S}$, utilization of S was only $1.55 \%$ in comparison with $80 \mathrm{~kg}$ $\mathrm{N} \mathrm{ha}{ }^{-1}$. Taking into account all the fertilizer combinations with $\mathrm{N}$ and $\mathrm{S}$, we can conclude that the highest utilization of $\mathrm{N}\left(\mathrm{U}_{\mathrm{N}}\right)$ and the best final efficiency index of $\mathrm{N}$ and $\mathrm{S}$ (EFI) resulted from the combined application of $80 \mathrm{~kg} \mathrm{~N} \mathrm{ha}^{-1}$ and $50 \mathrm{~kg} \mathrm{~S} \mathrm{ha}^{-1}$. This combination should be recommended in practice for $\mathrm{N}$ and $\mathrm{S}$ fertilization of spring wheat. This is because increasing the $\mathrm{N}$ application rate to $120 \mathrm{~kg} \mathrm{ha}^{-1}$ causes a decrease in utilization of $\mathrm{N}\left(\mathrm{U}_{\mathrm{N}}\right)$, and adding $\mathrm{S}$ causes a decrease in utilization of $\mathrm{S}\left(\mathrm{U}_{\mathrm{S}}\right)$ by the grain. This phenomenon should be explained by the law of decreasing increments (Mitscherlich law) [9]. Wojciechowski [37] demonstrated that after the increase in the application rate from 40 to $80 \mathrm{~kg} \mathrm{ha}^{-1}$, $\mathrm{N}$ utilization was $38.6 \%$ higher than for the fertilization range of $80-120 \mathrm{~kg}$, and $72.7 \%$ higher than for $0-40 \mathrm{~kg} \mathrm{ha}^{-1}$. In the study of Shivay et al. [1], $5 \%$ of S-coated urea (SCU) supplied $50 \%$ of the S needs of the wheat crop and increased recovery efficiency by $60.3 \%$ over $\mathrm{N}$ application as uncoated prilled urea (PU). According to Monaghan et al. [27], 50\% of S accumulated in the kernels is taken up by wheat in the period after flowering. Thus the selection of fertilizer for spring wheat and other cereals should take into account the demand of this species for $\mathrm{S}$ during the entire vegetative season, i.e., both in the stem elongation stage [3] and near the end of vegetation $[9,38-40]$.

\section{Conclusions}

Polish agriculture must use the rules of an integrated production system. Then it should be taken into account that the application of mineral nutrients should be lower than the plant uptake level. In this situation spring wheat fertilization with $80 \mathrm{~kg} \mathrm{~N}^{-1}$ and $50 \mathrm{~kg} \mathrm{~S}^{-1}$ should be recommended in practice as the present study indicated that it guarantees the highest seed yield and the highest utilization of $\mathrm{N}$ from fertilizers. 


\section{References}

1. SHIVAY Y.S., POONIYA V., PRASAD R., PAL M., BANSAL R. S-coated urea as a source of $\mathrm{S}$ and an enhanced efficiency of $\mathrm{N}$ fertilizer for spring wheat. Cereal Res Commun., 44 (3), 513, 2016.

2. KLIKOCKA H., WYŁUPEK T., NAROLSKI B. S Content Analysis of Zamość Region Biosphere. Ochrona Środowiska, 37 (1), 33, 2015 [In Polish].

3. KLIKOCKA H., CYBULSKA $\mathrm{M}$. $\mathrm{S}$ and $\mathrm{N}$ fertilization of spring wheat. Mineral fertilization of spring wheat. Sarrbrucken, LAP Lambert Academic Publishing, 2014.

4. DOSTÁlOVÁ Y., HŘIVNA L., KOTKOVÁ B., BUREŠOVÁ I., JANEČKOVÁ M., ŠOTTNÍKOVÁ V. Effect of $\mathrm{N}$ and $\mathrm{S}$ fertilization on the quality of barley protein. Plant Soil and Environ., 61 (9), 399, 2015.

5. PILBEAM D.J.N. In: Barker A.V., Pilbeam D.J.: Handbook of Plant Nutrition. Second Edition. CRC PressTaylor \& Francis Group Boca Raton, London, New York, 2015.

6. HESSE H., NIKIFOROVA V., GAKIČRE B., HOEFGEN R. Molecular analysis and control of cysteine biosynthesis: Integration of $\mathrm{N}$ and $\mathrm{S}$ metabolism. J Exp Bot, 55, 1283, 2004.

7. SZCZEPANIAK W. Evaluating N Use Efficiency (NUE) Indices on the Background of Mineral Status of the Seed Crop at Maturity: a Case Study of Maize. Pol. J. Environ. Stud., 25 (5), 2129, 2016.

8. KLIKOCKA H., CYBULSKA M., BARCZAK B., NAROLSKI B., SZOSTAK B., KOBIAŁKA A., NOWAK A., WÓJCIK E. The effect of $\mathrm{S}$ and $\mathrm{N}$ on grain yield and technological quality of spring wheat. Plant Soil Environ., 62 (5), 230, 2016.

9. GRZEBISZ W. Fertilization of crops. Part II. Fertilisers and fertilization systems. The basics of fertilizing. PWRiL, Poznań, 2009 [In Polish].

10. ERCOLI L., LULLI L., ARDUINI I., MARIOTTI M., MASONI A. Durum wheat grain yield and quality as affected by $\mathrm{S}$ rate under Mediterranean conditions. Europ. J. Agron., 35, 63, 2011.

11. POTARZYCKI J. Single superphosphate as a source of $\mathrm{S}$ for spring barley. II. $\mathrm{N}$ and $\mathrm{S}$ utilization from fertilizers. Nawozy Nawoż.-Fert. Fertil., 4 (17), 193, 2003 [In Polish].

12. PODLEŚNA A. Studie on the role of sulfur at forming of mineral management and height and quality of chosen crops yield. Habilitation thesis. Monografie i rozprawy naukowe 37. IUNG Puławy, 2013 [In Polish].

13. KNAPOWSKI T., KOZERA W., MAJCHERCZAK E., BARCZAK B. Effect of $\mathrm{N}$ and zinc fertilization on chemical composition and protein yield of spring triticale. Fragm. Agron., 27 (4), 45, 2010 [In Polish].

14. FLOOD R.G., MARTIN P.J. 2001. N accumulation and distribution at anthesis and maturity in the wheats grown at three sites in north-western Victoria. Austral., J. Exp. Agric., 41 (4), 533, 2001.

15. BÄNZIGER M. N efficiency of spring wheat genotypes (Triticum aestivum L.). Dissertation Doctor of Natural Science. Swiss Federal Instit. Tech. Zürich, 1992.

16. PODLEŚNA A., CACAK-PIETRZAK G., SOWIŃSKI M. Response of winter wheat to fertilizing $S$ in the field experiment. Nawozy Nawoż.-Fert. Fertil., 4 (17), 169, 2003 [In Polish].

17. PODLEŚNA A., CACAK-PIETRZAK G. Formation of the spring wheat yield as well as its milling and baking parameters by $\mathrm{N}$ and sulfur fertilization. Pam. Puł., 42, 382, 2006 [In Polish].

18. POTARZYCKI J., PRZYGOCKA-CYNA K., WENDEL. J., BINIEK Ł., RIDIGER B. The impact of S fertilization on yield of winter wheat. Fragm. Agron., 32 (4), 63, 2015 [In Polish].

19. ZHAO F.J., SALMON S.E., WITHERS P.J.A., EVANS E.J., MONAGHAN J.M., SHEWRY P.R., MCGRATH S.P. Responses of breadmaking quality to $\mathrm{S}$ in three wheat varieties. J. Sci. Food Agric., 79, 1865, 1999.

20. PRZYGOCKA-CYNA K., GRZEBISZ W. Yield and technological quality of malting barley in response to elemental S application. Nawozy Nawoż.-Fert. Fertil., 3 (28), 5, 2006 [In Polish].

21. PRZYGOCKA-CYNA K., GRZEBISZ W. S accumulation by barley plants and its economy during grain filling in response to elemental S application. Nawozy Nawoż.-Fert. Fertil., 3 (28), 40, 2006 [In Polish].

22. BARCZAK B. Sulfur as a nutrient determining the yield and quality of selected crop species. Habilitation thesis 144. Wyd. UTP Bydgoszcz, 2010.

23. MARTIN R.J. Uptake and distribution of $\mathrm{N}$ and $\mathrm{S}$ in two Otane wheat crops. Proceedings Agron. Society N.Z., 27, 19, 1997.

24. REUSSI N., ECHEVERRIA H., ROZAS H.S. Diagnosing sulfur deficiency in spring red wheat: plant analysis. J. Plant Nutr., 34 (4), 573, 2011.

25. HOWARTH J.R., PARMAR S., JONES J., SHEPHERD C.E., COROL D.I., GALSTER A.M., HAWKINS N.D., MILLER S.J., BAKER J.M., VERRIER P.J., WARD J.L., BEALE M.H., BARRACLOUGH P.B., HAWKESFORD M.J. Co-ordinated expression of amino acid metabolism in response to $\mathrm{N}$ and $\mathrm{S}$ deficiency during wheat grain filling. J. Exp. Bot., 59 (13), 3675, 2008.

26. GONDEK K., GONDEK A. The influence of mineral fertilization on the yield and the content of the selected macro and microelements in spring wheat. J. Res. Appl. Agric. Eng., 55 (1), 30, 2010 [In Polish].

27. MONOGHAN J.M., SCRIMGEOUR C.M., STEIN W., ZHAO F.J., EVANS E.J. S accumulation and redistribution in wheat a study using stable isotoperatios as a tracer system S. Plant, Cell \& Environ., 22 (7), 831, 1999.

28. KOVAR J., GRANT C. Nutrient cycling in soil: sulfur. Ed. HATFIELD J.L., SAUER T.J. In: Soil Menagement: Building a Stable Base for Agriculture: 103, 2011.

29. BARCZAK B., NOWAK K. Amino acid composition protein biomass winter barley (Hordeum vulgare L.), depending on the state of development of the plant and fertilize with N. Acta Sci. Pol. Agricultura, 7 (1), 3, 2008 [In Polish].

30. FOTYMA E. Effect of sulfur on $\mathrm{N}$ utilization of mineral fertilizers by field crops. Nawozy Nawoż.-Fert. Fertil., 4 (17), 117, 2003 [In Polish].

31. FOTYMA E. 1990. Identify needs fertilizer plants in relation to the $\mathrm{N}$ on the example of spring barley. Fragm. Agron., 4 (28), 4, 1990 [In Polish].

32. RUTKOWSKA A. Studies on fertilization of winter wheat with N. Nawozy Nawoż.-Fert. Fertil., 4 (21), 2004 [In Polish].

33. ZHANG J., LI Z.H., LI K., HUANG W., SANG L.H. N use efficiency under different field treatments on maize fields in Central China: a lysimeter and ${ }^{15} \mathrm{~N}$ study. J. Water Resource Prot., 4, 590, 2012.

34. HIREL B., TÉTU T., LEA P., DUBOIS F. Improving N use efficiency in crops for sustainable agriculture. Sustainability, 3, 1452, 2011. 
35. POTARZYCKI J. Simple superphosphate as a source of S for spring barley. Part. I. Yield and grain quality. Nawozy Nawoż.-Fert. Fertil., 4 (17), 180, 2003 [In Polish].

36. SALVAGIOTTI F., CASTELLARÍN J.M., MIRALLES D.J., PEDROL H.M. Sulfur fertilization improves N use efficiency in wheat by increasing $\mathrm{N}$ uptake. Field Crop Res., 113 (2), 170, 2009.

37. WOJCIECHOWSKI W. The importance of catch crops for optimizing $\mathrm{N}$ fertilization of quality spring wheat. Wyd. UP Wrocław, 2009 [In Polish].
38. KLIKOCKA, B. NAROLSKI., G. MICHAŁKIEWICZ. The effects of tillage and soil mineral fertilization on the yield and yield components of spring barley. Plant Soil Environ., 60 (6), 255, 2014.

39. ERIKSEN J., NIELSEN M., MORTENSEN J.V., SCHJØRRING J.K. Redistribution of S during generative growth of barley plants with different $\mathrm{S}$ and $\mathrm{N}$ status. Plant and Soil, 230, 239, 2001.

40. ERIKSEN J., MORTENSEN J.V. Effects of timing of S application on yield, S-uptake and quality of barley. Plant and Soil, 242, 283, 2002. 